\title{
Influence of photoperiod on body weight and depth of burrowing in larvae of Chrysomya megacephala (Fabricius) (Diptera, Calliphoridae) and implications for forensic entomology
}

\author{
Leonardo Gomes ${ }^{1}$, Guilherme Gomes, Helena Gutierrez Oliveira, Marcos Rogério Sanches \\ \& Claudio José Von Zuben
}

${ }^{1}$ Departamento de Zoologia, Instituto de Biociências, Universidade Estadual Paulista (UNESP), Campus de Rio Claro, Avenida 24-A,
Bairro Bella Vista, 1515, 13506-900 Rio Claro-SP, Brazil. leugomes@ yahoo.com.br

\begin{abstract}
Influence of photoperiod on body weight and depth of burrowing in larvae of Chrysomya megacephala (Fabricius) (Diptera, Calliphoridae) and implications for forensic entomology. Blowflies use discrete, ephemeral breeding sites for larval nutrition. After exhaustion of the food supply, the larvae disperse in search of sites to pupate or to seek other sources of food in a process known as post-feeding larval dispersal. In this study, some of the most important aspects of this process were investigated in larvae of the blowflies Chrysomya megacephala exposed to a variety of light: dark (LD) cycles $(0: 0 \mathrm{~h}, 12: 12 \mathrm{~h}$ and 24:0 h) and incubated in tubes covered with vermiculite. For each pupa, the body weight and depth of burrowing were determined. Statistical tests were used to examine the relationship of depth of burrowing and body weight to photoperiod at which burrowing occurred. The study of burial behavior in post-feeding larval dispersing can be useful for estimating the postmortem interval (PMI) of human corpses in forensic medicine.
\end{abstract}

KEYWORDS. Blowflies; crime; legal medicine.

RESUMO. A influência do fotoperíodo no peso corpóreo e na profundidade de enterramento em larvas de Chrysomya megacephala (Fabricius) (Diptera, Calliphoridae) e as implicações para entomologia forense. Moscas-varejeiras usam substratos discretos e efêmeros para nutrição larval. Após a exaustão do suprimento de comida, as larvas dispersam na procura por locais para pupação na outros recursos de alimento em um processo conhecido como dispersão larval pósalimentar. Nesse estudo, alguns dos aspectos mais importantes desse processo foram investigados em larvas de moscasvarejeiras Chrysomya megacephala expostas a uma variação de ciclos luz: escuro (LD) $(0: 24 \mathrm{~h}, 12: 12 \mathrm{~h}$ e $24: 0 \mathrm{~h})$ e incubadas em tubos cobertos com vermiculita. Para cada pupa, o peso corpóreo e a profundidade de enterramento foram determinados. Testes estatísticos foram usados para examinar a relação entre profundidade de enterramento e o peso corpóreo e o fotoperíodo a que esse enterramento ocorreu. O estudo do comportamento de enterramento na dispersão larval pós-alimentar pode ser útil para estimar o intervalo pós-morte (IPM) em cadáveres humanos em medicina forense.

PALAVRAS-CHAVE. Crime; medicina legal; moscas-varejeiras.

Photoperiod regulation is widespread in terrestrial organisms, including flowering plants, fungi, birds, mammals, molluscs and arthropods (Hastings 2001). Among insects, such seasonality has been recorded in over 500 species from 17 orders (Nishizuka et al. 1998). This wide occurrence suggests that the phenomenon is very common, especially among insects from temperate regions with well marked seasonal changes. Most attention has been given to the important phenomenon of diapause, although many other seasonally important strategies are known (e.g. aspects of cold tolerance, migration and growth) (Saunders 2002).

Insect development is affected by many factors, particularly environmental conditions. Temperature and photoperiod is the most important factor affecting the rate of development (Myskowiak \& Doums 2002; Feng et al. 2002a) and, in forensic medicine, an understanding of blowfly development is important for estimating the time elapsed since death (the postmortem interval or PMI) (Feng et al. 2002b; Grassberger \& Reiter 2003; Lefbvere \& Pasquerault 2004; Gomes \& Von Zuben 2004a; Gomes et al. 2005).
Blowflies belonging to the family Calliphoridae are ecologically diverse and occupy various habitats. These flies develop in various substrates, from decomposing organic matter to live animal tissues (Zumpt 1965).

Blowflies of the genera Chrysomya are of considerable medical and sanitary importance since they carry enteropathogens such as viruses, bacteria and helminths (Furlanetto et al. 1984; Lima \& Luz 1991) and may cause myiasis in animals and men (Zumpt 1965; Guimarães 1983). These flies are also important in forensic entomology since they can be used to determine the decomposition time of human cadavers PMI (Smith 1986; Greenberg 1990; Von Zuben 1996; Gomes \& Von Zuben 2004b).

The substrates in which blowflies develop are discrete and ephemeral (Backer 1969; Backer 1971; Atkinson \& Shorrocks 1981; Ives 1989; Ives 1991), so that the larval stage is the main period in which blowflies face limited food resources. Since these substrates are normally saturated with insects of one or more species, there is often intense competition for resources (Hanski 1987). The competition for these resources is generally 
of the exploitative type (Levot et al. 1979; Reis et al. 1994) in which each larva attempts to feed as much as possible before the food supply finishes (Ullyett 1950; de Jong 1976; Lominicki 1988). Following this competition, the larvae leave to search for a place to pupate, or for another source of food if they are not heavy enough to pupate. This process is known as postfeeding larval dispersal (Gomes et al. 2002; Gomes \& Von Zuben 2003; Gomes et al. 2003). During this dispersal, the larvae have to deal with various environmental factors, the most important being temperature (Gomes \& Von Zuben 2004a) and photoperiod.

Several laboratory studies have investigated post-feeding larval dispersion in blowflies (Greenberg 1990; Gomes et al. 2002; Gomes \& Von Zuben 2003; Gomes et al. 2003). Although some field studies have also been reported (Greenberg 1990), most have suffered from the inability to control environmental variables as easily as in the laboratory. This is a critical consideration since one of the most important questions is how climatic conditions can affect post-feeding larval dispersal and the subsequent burrowing of the larvae prior to pupation. To address this question, in this study, we used a simulated natural environment to examine the burrowing capacity of $C$. megacephala larvae and to determine the relationship between the depth of burrowing and environmental factors such photoperiod.

\section{MATERIAL AND METHODS}

Specimens of $C$. megacephala were collected close to the campus of the Universidade Estadual Paulista, Rio Claro, São Paulo, Brazil. Adult blowflies were maintained in the laboratory at $25 \pm 1^{\circ} \mathrm{C}$ in cages $(30 \times 30 \times 30 \mathrm{~cm})$ covered with nylon and were fed water and sugar ad libitum. Adult females were fed fresh beef liver to allow complete development of the gonotrophic cycle. Newly hatched larvae of both species were obtained from adult flies kept at $25^{\circ} \mathrm{C}$ and $60 \pm 10 \%$ relative humidity, and were raised in vials containing $50 \mathrm{~g}$ of ground beef.

Three hundred third instar $\left(\mathrm{L}_{3}\right)$ larvae (grew in the same experimental conditions of this study) of C. megacephala were used for these experiments. The larvae (100 per treatment group) were placed individually in dark test tubes $(20 \mathrm{~cm} \times 1.5$ $\mathrm{cm})$ containing vermiculite and incubated at $60 \pm 10 \%$ relative humidity at $25^{\circ} \mathrm{C}$ on light: dark (LD) cycles of $0: 24 \mathrm{~h}, 12: 12 \mathrm{~h}$ and 24:0 h. These conditions, including tube size, were used to ensure that any movement of the larvae was directed towards burrowing. Previous work (Gomes \& Von Zuben 2004a) demonstrated that, regardless of the type of substrate available for pupation, the larvae did not bury themselves deeper than an average of $20 \mathrm{~cm}$.

After they had pupated, the larvae were located and removed from the vermiculite. The depth of the pupation site was measured with a ruler. Each pupa was then placed separately in a plastic flask and weighed on an Ohaus analytical balance before emerging as an adult. Pupal weight was measured in milligrams, with a precision of $0.01 \mathrm{mg}$, as soon as the pupae were located. After weighing, each pupa was returned to its flask for sexing following emergence of the adult.

The results were expressed as the mean + standard deviation (S.D.). ANOVA was used to compare the means of variables (Zar 1999). A value of $\mathrm{p}<0.05$ indicated significance.

\section{RESULTS ANDDISCUSSION}

Table I show the body weight and the depth of burrowing for C. megacephala larvae, respectively, in relation to the photoperiod. The depth of burrowing varied considerably with the photoperiod, in spite of inside the substrate for pupation it didn't happen.

In this species, the depth of burrowing significantly increased with increasing photoperiod (ANOVA, $\mathrm{F}_{2,298}=30.92$, $\mathrm{P}<0.0001)$ but no significant effect of photoperiod on larval body weight were detected (ANOVA, $\mathrm{F}_{2,298}=0.10, \mathrm{P}<0.0001$ ).

The boxplots (Figs. 1, 2) shows the relationship between the depth of burrowing and the photoperiod and the effect of photoperiod on body weight in larvae of $C$. megacephala respectively. These plots help to visualization the variations in larval weight and depth of burrowing in the different photoperiods. In photoperiod $0 \mathrm{~h}$, the depth of burrowing was broadly distributed above and below the median value, although the variability (distance between the maximum and minimum) was not very big. A similar situation was seen with a photoperiod of $12 \mathrm{~h}$. In contrast, for the $24 \mathrm{~h}$ photoperiod, there was much greater variability in depth of burrowing, with the larvae digging deeper than the median and dispersing more ( 7 to $13 \mathrm{~cm}$ from the site). There was little variation in larval weight in the various photoperiods, particularly in the $24 \mathrm{~h}$ photoperiod, during which this weight was more uniform.

In relation to depth (Figure 1), when the photoperiod is 24 $\mathrm{h}: 0 \mathrm{~h}$ (totally illuminated), the median don't superpose to the intervals from other photoperiod, what justify the high significance found in the difference between averages (ANOVA), what doesn't happened with in relation with weight.

Considering the sex, it was observed that the weightiest larvae were females when compared with the males (Table II), and it was a significant effect (ANOVA, $\mathrm{F}_{2,299}=0.01, \mathrm{P}<0.0001$ ) when compared with the depth (ANOVA, $\mathrm{F}_{2,299}=0.10, \mathrm{P}<0.0001$ ).

The photoperiod didn't affect the weight of burrowing to a similar extent in this species, whereas temperature had

Table I. Body weight and depth of burrowing for C. megacephala larvae in different photoperiods.

\begin{tabular}{lcccc}
\hline Parameter & $\begin{array}{c}\text { Photoperiod } \\
\text { (light hours) }\end{array}$ & $\mathrm{N}$ & Mean & S.D. \\
\hline Body weight & 0 & 100 & 38.3 & 7.1 \\
& 12 & 100 & 38.0 & 6.9 \\
& 24 & 100 & 38.6 & 3.5 \\
& Total & 300 & 38.3 & 6.0 \\
Depth of burrowing & 0 & 100 & 3.1 & 1.9 \\
& 12 & 100 & 4.3 & 3.0 \\
& 24 & 100 & 8.0 & 3.6 \\
& Total & 300 & 5.1 & 3.6 \\
\hline
\end{tabular}




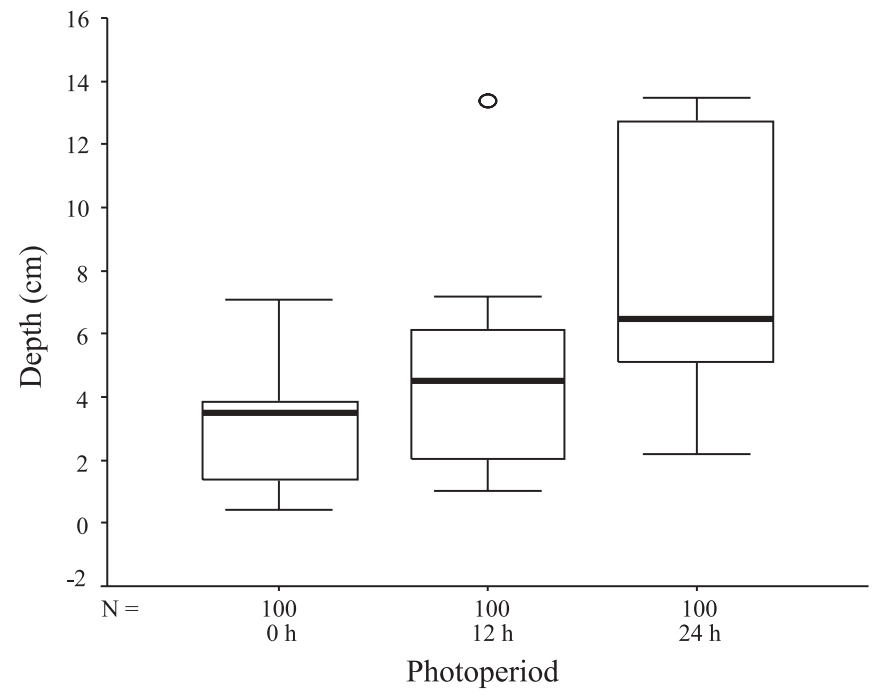

Fig. 1. Relationship between the depth of burrowing and the photoperiod for larvae of $C$. megacephala. The corresponding boxplot for each photoperiod consists of five parts: 1) the horizontal bar below the box indicates the lowest value recorded (e.g. the lightest larva), 2) the lower horizontal bar of the box represents the first quartile (25\% of the larvae weighed less than this value), 3) the horizontal bar in bold in the middle of the box represents the median $(50 \%$ of the larvae weighed less than this value), 4) the upper horizontal bar of the box corresponds to the third quartile ( $75 \%$ of the larvae weighed less than this value), and 5) the horizontal bar above the box represents the highest value recorded (e.g. the heaviest larva). The points or circles indicate extreme values.

essentially opposite effects on this parameter (Gomes \& Von Zuben 2004a). Meanwhile, the effect of photoperiod in larvae of $C$. megacephala was that the depth of burrowing increased with increasing photoperiod and no significant effect of photoperiod on larval body weight were found.

Studies of post-feeding larval dispersion are important for criminal investigations in forensic medicine since the presence of larvae and pupae in and around human cadavers can be helpful in estimating the PMI. Estimation of the PMI is a fundamental aspect of legal medicine (Smith 1986), but can be seriously compromised by an inadequate consideration of post-feeding larval dispersal (Gomes et al. 2002; Gomes et al. 2003) and of the environmental factors involved in such dispersal, including temperature and photoperiod (Feng et al. 2002a; Grassberger \& Reiter 2003). However, in PMI evaluations, great caution must be applied when using data

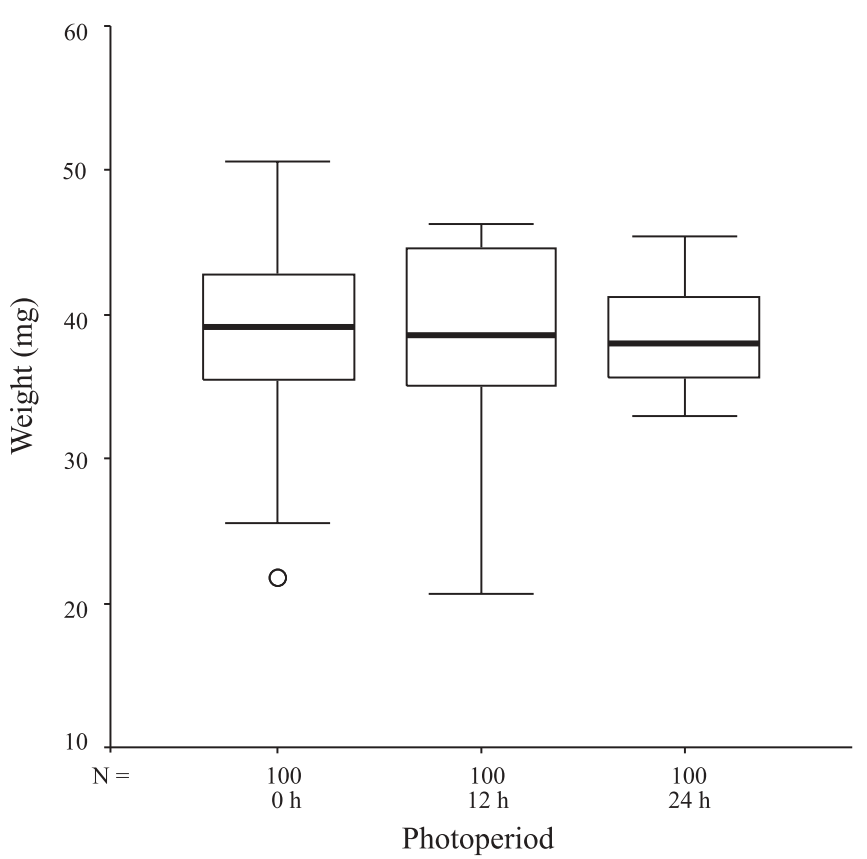

Fig 2. Relationship between the weight of burrowing and the photoperiod for larvae of $C$. megacephala. The corresponding boxplot for each photoperiod consists of five parts: 1) the horizontal bar below the box indicates the lowest value recorded (e.g. the lightest larva), 2) the lower horizontal bar of the box represents the first quartile $(25 \%$ of the larvae weighed less than this value), 3) the horizontal bar in bold in the middle of the box represents the median $(50 \%$ of the larvae weighed less than this value), 4) the upper horizontal bar of the box corresponds to the third quartile ( $75 \%$ of the larvae weighed less than this value), and 5) the horizontal bar above the box represents the highest value recorded (e.g. the heaviest larva). The points or circles indicate extreme values.

collected by researchers form other countries. Changes in range and precipitation, which may lead species to change their time of hatching, length of life cycle, photoperiod and diapause, must all be taken in consideration (Turchetto \& Vanin 2004).

This is a critical consideration since one of the most important questions is how climatic conditions can affect postfeeding larval dispersal and the subsequent burrowing of the larvae prior to pupation. An analysis of environmental factors, particularly photoperiod, can be helpful when searching for dispersing larvae around cadavers, e.g., in closed locations with an LD cycle of 0:24 h, or in totally illuminated locations

Table II. Depth and weight of larvae of C. megacephala considering the sex.

\begin{tabular}{|c|c|c|c|c|c|c|c|c|c|}
\hline \multirow{2}{*}{\multicolumn{2}{|c|}{ Descriptives }} & \multirow[b]{2}{*}{$\mathrm{N}$} & \multirow[b]{2}{*}{ Mean } & \multirow[b]{2}{*}{ Std. Deviation } & \multirow[b]{2}{*}{ Std. Error } & \multicolumn{2}{|c|}{$\begin{array}{l}95 \% \text { Confidence } \\
\text { Interval for Mean }\end{array}$} & \multirow[b]{2}{*}{ Minimum } & \multirow[b]{2}{*}{ Maximum } \\
\hline & & & & & & Lower Bound & Upper Bound & & \\
\hline \multirow{3}{*}{ Depth } & $\mathrm{F}$ & 158 & 4.988 & 3.2454 & .4261 & 4.135 & 5.841 & 1.0 & 13.5 \\
\hline & $\mathrm{M}$ & 142 & 5.054 & 3.7359 & .5181 & 4.014 & 6.094 & .4 & 13.5 \\
\hline & Total & 300 & 5.019 & 3.4697 & .3308 & 4.363 & 5.675 & .4 & 13.5 \\
\hline \multirow{3}{*}{ Weight } & $\mathrm{F}$ & 158 & 39.155 & 5.5504 & .7288 & 37.696 & 40.615 & 20.7 & 50.6 \\
\hline & M & 142 & 37.090 & 6.6826 & .9267 & 35.230 & 38.951 & 20.7 & 50.6 \\
\hline & Total & 300 & 38.179 & 6.1707 & .5883 & 37.013 & 39.345 & 20.7 & 50.6 \\
\hline
\end{tabular}


with an LD cycle of 24:0 $\mathrm{h}$ could be helpful in detecting the effect of interval of photoperiod at which the maximum depth of burrowing occurs and at which the number of burrowing larvae is also maximal (Gomes \& Von Zuben 2004a).

Furthermore, it can be underestimated if older dispersing larvae or those that disperse father, faster and deeper are not taken into account (Gomes et al. 2002; Gomes et al. 2003; Gomes \& Von Zuben 2005). Because of this, it is necessary to investigate the pattern of larval dispersal on the pupation site and the burial behavior after this process, as demonstrated in this study with larvae of $C$. megacephala, regardless the environmental conditions, such photoperiod.

Acknowledgments. The authors thank Iracema Monteiro da Silva. L. Gomes was supported by a fellowship from FAPESP (03/00540-3) and C. J. Von Zuben by a research fellowship from CNPq. Thanks to Dr Stephen Hyslop by reviewing the English.

\section{REFERENCES}

Atkinson, W. D. \& B. Shorrocks. 1981. Competition on a divided and ephemeral resource: a simulation model. Journal of Animal Ecology 50: 461-471.

Backer, K. 1969. Selection for rate of growth and its influence on competitive ability of larvae of Drosophila melanogaster. Netherland Journal of Zoology 19: 541-595.

Backer, K. 1971. An analysis of factors which determine success in competition for food among larvae of Drosophila melanogaster. Archives of Neederland Zoology 14: 200-281.

de Jong, G. 1976. A model of competition for food. I. Frequencydependent viabilities. American Naturalist 110: 1013-1027.

Feng, W. C.; H. Cui; C. Y. Chuan; M. J. Xiong; L. J. Tao; J. F. Wang; C. Hu; Y. C. Chen; J. X. Min \& J. T. Li. 2002a. Chronology of development within puparium of Chrysomya megecephala in different constant temperature and its application in postmortem interval. Acta Parasitology of Medical Entomology Sin 8: $232-236$.

Feng, W. C.; H. Cui; C. Y. Chuan; M. J. Xiong; L. J. Tao; J. F. Wang; C. Hu; Y. C. Chen; J. X. Min \& J. T. Li. 2002b. Effect of temperature over the body-length change of Chrysomya megacephala (Fabrius). Acta Parasitology of Medical Entomology Sin 9: 100-105.

Furlanetto, S. M. P.; M. L. C. Campos; C. M. Hársi; G. M. Buralli \& G. H. Ishihata. 1984. Microrganismos enteropatogênicos em moscas africanas pertencentes ao gênero Chrysomya (Diptera: Calliphoridae) no Brasil. Revista de Microbiologia 15: 170174.

Gomes, L.; C. J. Von Zuben \& J. S. Govone, J. S. 2002. Comportamento da dispersão larval radial pós-alimentar em moscas-varejeiras do gênero Chrysomya (Diptera: Calliphoridae): busca por novas fontes de alimento. Entomologia y Vectores 9: 115-132.

Gomes, L. \& C. J. Von Zuben. 2003. Dispersão larval pós-alimentar em Chrysomya megacephala (F.) (Diptera: Calliphoridae): profundidade, distância e peso de enterramento para pupariação. Bioscience Journal 18: 67-76.

Gomes, L. C. J. Von Zuben \& M. R. Sanches. 2003. Estudo da dispersão larval radial pós-alimentar em Chrysomya megacephala (F.) (Diptera: Calliphoridae). Revista Brasileira de Entomologia 47: $229-234$.

Gomes, L \& C. J. Von Zuben. 2004a. Efeito da temperatura na profundidade de enterramento de larvas de Chrysomya megacephala (Wied.) (Diptera: Calliphoridae). Entomologia y Vectores 11: 551-557.

Gomes, L. \& C. J. Von Zuben. 2004b. Dispersão larval radial pósalimentar em Lucilia cuprina (Diptera, Calliphoridae): profundidade, peso e distância de enterramento para pupação. Iheringia, Série Zoologia 94: 135-138.
Gomes, L. \& C. J. Von Zuben. 2005 Postfeeding radial dispersal in larvae of Chrysomya albiceps (Diptera: Calliphoridae): implications for forensic entomology. Forensic Science International 155: 61-64.

Gomes, L; M. R. Sanches \& C. J. Von Zuben. 2005. Dispersal and burial behavior in larvae of Chrysomya megacephala and Chrysomya albiceps (Diptera, Calliphoridae). Journal of Insect Behavior 18: $281-292$.

Grassberger, M. \& C. Reiter. 2003. Effect of temperature on development of the forensically important holartic blow fly Protophormia terraenovae (Robineau- Desvoidy) (Diptera: Calliphoridae). Forensic Science International 128: 177-182.

Greenberg, B. 1990. Behavior of postfeeding larvae of some Calliphoridae and amuscid (Diptera). Annals of Entomological Society of America 83: 1210-1214.

Guimarães, J. H.; N. Papavero \& A. P. Prado. 1983. As mí́ases na região neotropical (identificação, biologia, bibliografia). Revista Brasileira de Zoologia 1: 239-416.

Hanski, I. 1987. Carrion fly community dynamics: patchiness, seasonality and coexistence. Ecological Entomology 12: 257266.

Hastings, M. H. 2001. Adaptation to seasonal change: photoperiodism and its mechanism. Journal of Biological Rhytims 16: 283430.

Ives, A. R. 1989. The optimal clutch size of insects when many females oviposit per patch. American Naturalist 133: 671-687.

Ives, A. R. 1991. Aggregation and coexistence in a carrion fly community. Ecological Monographs 61: 75-94.

Lefbvere, F. \& T. Pasquerault. 2004. Temperature-dependent development of Ophyra aenescens (Wiedemann 1830) and Ophyra capensis (Wiedemann 1818) (Diptera, Muscidae). Forensic Science International 139: 75-79.

Levot, G. W.; K. R. Brown \& E. Shipp. 1979. Larval growth of some calliphorid and sarcophagid Diptera. Bulletin of Entomological Research 69: 469-475.

Lima, M. L. P. S. \& E. Luz. 1991. Espécies exóticas de Chrysomya (Diptera, Calliphoridae) como veiculadoras de enterobactérias patogênicas em Curitiba, Paraná, Brasil. Acta Biológica do Paraná 20: $61-83$.

Lomnicki, A. 1988. Population Ecology of Individuals. Princeton: Princeton Press, 233 p.

Myskowiak, J. B. \& C. Doums. 2002. Effects of refrigeration on the biometry and development of Protophormia terraenovae (RobineauDesvoidy) (Diptera: Calliphoridae) and its consequences in estimating the post-mortem interval in forensic investigations. Forensic Science International 125: 254-261.

Nishizuka, M; A. Azuma \& S. Masaki. 1998. Diapause response to photoperiod and temperature in Lepisma saccharina Linnaeus (Thysanura, Lepismatidae). Entomological Science 1: 7-14.

Reis, S. F.; G. Stangenhaus; W. A. C. Godoy; C. J. Von Zuben \& O. B. Ribeiro. 1994. Variação em caracteres bionômicos em função de densidade larval em Chrysomya megacepala e Chrysomya putoria (Diptera : Calliphoridae). Revista Brasileira de Entomologia 38: 33-34.

Saunders, D. S. 2002. Insects clocks. $3^{\text {rd }}$ edn. Elsevier Science BV: Amsterdam.

Smith, K. G. V. 1986. A manual of forensic entomology. Ithaca: Cornell University Press, $475 \mathrm{p}$.

Turchetto, M. \& S. Vanin. 2004. Forensic entomology and climatic change. Forensic Science International 146: S195-S199.

Ullyett, G. C. 1950. Competition for food and allied phenomena in sheep-blowfly populations. Philosophical Transactions of Royal Society of London B 234: 77-174.

Von Zuben, C. J. 1996. Comportamento de oviposturas individuais, percentagem de eclosão e peso larval mínimo para pupação em populações de Chrysomya megacephala (F.). Anais da Sociedade Entomológica do Brasil 4: 525-533.

Zar, J. H. 1999. Biostatistical Analysis. New Jersey: Prentice Hall, $666 \mathrm{p}$.

Zumpt, F. 1965. Myiasis in man and animals in the old world. London: Butterworths, $267 \mathrm{p}$. 